\title{
A society which is not: Political emergence and migrant agency
}

Stefan Jonsson

The self-archived postprint version of this journal article is available at Linköping University Institutional Repository (DiVA):

http://urn.kb.se/resolve?urn=urn:nbn:se:liu:diva-163430

N.B.: When citing this work, cite the original publication.

Jonsson, S., (2020), A society which is not: Political emergence and migrant agency, Current Sociology, , 1-19. https://doi.org/10.1177/0011392119886863

Original publication available at:

https://doi.org/10.1177/0011392119886863

Copyright: SAGE Publications (UK and US)

http://www.uk.sagepub.com/home.nav 


\section{Stefan Jonsson, REMESO, Linköping University}

\section{A Society which Is Not: Political Emergence and Migrant Agency}

Current Sociology 2020

It is a truism, of course, that scholarship in the human sciences change with the times, adapting to historical pressures and societal challenges. If migration, political protest and colonial legacies move to the centre of the times, they can't still be treated as aberrations, of peripheral concern, in the human sciences, or can they? Transformations of paradigms are usually contested and controversial. It is only with difficulty that sociology and political science have been able to incorporate into their pursuit of knowledge issues that were once seen as irrelevant or marginal but that have since gained in importance - and when it happens it usually occurs under the sign of interdisciplinarity. Migration, colonialism and political protest are examples of such issues today. They fit poorly into the 'model society' that the social sciences were built to analyse and explain.

In one of the defining controversies in the history of sociology Theodor Adorno took Karl Popper and his followers in the school of 'critical rationalism' to task for producing knowledge that served the status quo (Adorno 1969/1976). What has gone down in intellectual history as the positivism dispute - 'der Positivismus Streit' - staked out a conflict, which has often been blown out of proportion, between putative 'positivists' and 'critical theorists'. On the one side were those who embraced Weberian impartiality, 'Wertfreiheit', arguing that sociology should deal only with problems that could be empirically analysed and rationally resolved. On the other side were those who argued that sociology's most important problems were such that they could be neither objectively accounted for, nor resolved, because they stemmed from social contradictions running so deep that they preconditioned the ways in which the human sciences framed their problems.

In his response to Popper, Adorno claimed the progressive roots of sociology (Comte, Durkheim) for his own brand of critical theory. A sociological inquiry faithful to the discipline's emancipatory thrust, persisting in its exploration of the conditions of social improvement and human freedom, had to shed its positivist fixation on existing society and refine its dialectical ability to 'experience the contradictory character of social reality', Adorno wrote. He emphasized that this commitment was a precondition of sociological knowledge: 'only the person who can conceptualize a different society from the existing one can experience it as a problem. Only through that which it is not, will it reveal itself as that which it is and this would presumably be fundamental in a sociology which, unlike the 
majority of its projects, would not be satisfied with ends laid down by public and private administration.' (Adorno 1969/1976: 120).

The following pages follow a path of sociological negation. What would be gained, if we took seriously the idea that migration, political protest or colonialism are not marginal to today's West-European societies, but indicative of the contradictions that these societies were built to contain and hence part of their constitution? I start out from the proposition that mainstream human sciences seem to be at an impasse because of their structural inability to interpret and explain systemic crises and contradictions. I will explore three expressions of this impasse. First, the human sciences often analyse migration without acknowledging its profound political implications (Hansen and Hager 2012; de Genova, ed. 2017). Second, European history and sociology rarely recognize histories of imperial dominance and anticolonial resistance as intrinsic to European history and society (Hansen and Jonsson 2014; Bhambra 2014; Jonsson and Willén, eds 2016). Third, mainstream social and political theory often ignore the structural significance of collective protests and resistance movements for the realization of democracy (Jonsson 2013; 2016).

I will frame my analysis of these problems by two theoretical contexts in which we can observe ongoing conceptual or methodological shifts or 'turns', by which the human sciences typically respond to the said impasse. In studies of democracy and citizenship there has thus been a clear turn toward 'borders'. In migration studies, there is a corresponding turn toward 'agency'. By analysing the interconnections between these theoretical contexts I hope to suggest ways to move ahead through the threefold impasse.

\section{The 'migration problem' as a political problem}

Now, by way of beginning this inquiry I should note that it is also prompted by a more urgent predicament, which appears to have thrown debate and discourse on the future of Europe and global society at the feet of two spectres: the migrant and the fascist. In mainstream rhetoric and media punditry, they are ominously coupled. We hear ever more statements to the effect that migration, if admitted in too great quantities, will necessarily generate reactions of white identitarianism, a scenario that conjures up dark memories when white or European culture rejected 'otherness' by perfecting systems of control, detention, deportation and extermination of supposedly alien populations.

This is the deep context in which we should understand a dominant ideological discourse of the West after the turn of the twenty-first century. When Angela Merkel stated in 2015 that the 'refugee crisis' of that year was 'a historic test for Europe' (Financial Times 2015), or 
when Jean-Claude Juncker shortly after contended that the migration challenge had brought 'Europe' to the brink of 'an existential crisis' (Juncker 2016: 16), or when a visiting Hillary Clinton recently said that 'Europe needs to get a handle on migration because that is what lit the flame' (Wintour 2018), they implicitly doubted whether Europe's white majority populations would stand contingents of migrants without compulsively repeating past crimes that would undercut the self-image of peace, cosmopolitanism and human rights by which the continent's leaders have laboriously sought to redress Europe's past in the postwar era. In fact, their statements betrayed a deeper worry: aren't Europe's leaders, in their efforts to prevent a return to fascism by preventing migrants from coming to Europe, already endorsing measures that repeat, albeit with a fresh set of excuses and motivations, the old authoritarian agenda that those same leaders at all costs want to avert?

The debate on Europe's so-called 'migration challenge' is indeed a contorted affair, rich in fear-mongering and false dilemmas (see Triandafyllidou 2017). Preservation of welfare systems has wrongly been pitted against refugee solidarity, and migration insidiously launched as an explanation of fascism. What there is to gather from this debate is perhaps no more, but also no less, than the idea that the political future of Europe hinges on how the fact of migration and the presence of migrants are understood. If they are today understood as exceptional problems, tomorrow will be nationalistic, racist or fascist. If migration and the presence of migrants are understood as perennial instances of human mobility, the future can be envisioned as in some sense cosmopolitan and transnational.

It follows, that the relation of migration to Europe's political future deserves serious consideration. It deserves consideration, I add, not because the 'migration problem' in Europe is in any sense greater than what it is in, say, South Asia or East Africa. On the contrary, Europe has done more than most other parts of the world to shield itself from migration and it is perfecting its apparatuses of state surveillance and violence so as to bar entry to people who have been forcibly displaced or claim refugee status. This notwithstanding, the disproportionate attention to Europe's 'migration problem' is in itself symptomatic of an issue worth pursuing. Apparently, only if processes of human mobility put pressure on states within the core of the world system, do such processes get designated as a societal challenge of the first order and theorized as 'international migration' in the strict sense, whereas other forms of cross-border movement are less spectacularly classified as 'mobility', if they get any attention at all. This incongruence discloses not only that Eurocentric perceptions still guide much reporting and scholarship on migration. It also indicates that Europe's 'migration problem' - 
portrayed as an exceptional 'challenge' or 'crisis' - is a trope for larger contradictions that derive from the unequal character of the world system itself (Boatca 2015).

A turn toward 'borders' in studies of democracy and citizenship

Migration and migrant presence thus emerge as Europe's major political issue. This development can be related to a parallel context in political theory where we observe vital efforts to rethink democracy and sovereignty in relation to borders. I argue that these two contexts combined enable a more precise understanding of the political implications of migration. This is because they together display how our conceptions of society depend on the postulate that sovereignty is a bounded entity. Or, put differently, if a community is defined by the way in which it demarcates itself in relation to the world through a specific boundary line, and if it attains its political identity through such demarcations, this amounts to saying that the political community is constituted by the imposition of a boundary.

It follows from this argument, and from the theory of Carl Schmitt (1927/2007) that is one of its sources, that we can distinguish between two notions of politics, a distinction which English language signifies by the difference between politics and the political, which in German translates into the difference between die Politik and das Politische, and in French between la politique and le politique (Mouffe 2005: 8-16; Badiou 1985; Lefort 1983: 71-88). According to a common definition of these terms 'politics' refers to affairs and actions of state institutions while 'the political' refers to the constitution and delimitation of a state or polity. In this view, 'politics' is the concern of the prime minister, the parliament, and the police, for instance. It is what chugs along in government committees, at party meetings and in newspaper editorials. It concerns itself with the maintenance of common, public and already constituted political order. By contrast, 'the political' is a reference to the constitution, consolidation or disintegration of such an order. The political is normally taken for granted as the pre-existing unshakeable foundation of politics, but it emerges into view in critical phases of history, for instance, in revolutionary moments when states are created or collapse, when constitutions are rewritten, or when political boundaries and populations are reshuffled.

Given this distinction, we realize that we should make a corresponding distinction within the field of migration studies. On the one hand, we can study migration politics: how state authorities, employers and civil society seek to manage migration flows and individual migrants according to particular needs and interests. Typically, this assumes the form of studying migration and integration policies: legal frameworks for entry, rights of residency 
and citizenship, paths of migrant groups toward education, employment and social benefits, various frameworks for migrant integration as well as mechanisms of discrimination.

On the other hand, we can study migration as an instance of the political institution of society. In this case, agency is no longer on the side of the state, the police, or other governmental or political institutions, but on the side of migration, now re-conceptualized as a proper social force that, by transgressing boundaries that have been established in order to demarcate communities, contributes to the reconstitution of these communities.

This is not to say that migrants make up a constituent political agency (conscious of itself as a power in itself). However, to the extent that migration today manifests specific responses to global crises and contradictions, it represents a plural force that transforms the political ordering of society. In this sense, the latter approach to contemporary migration confronts us with the problem of the political as such. From this perspective, the fact that governments see migration control as an increasingly critical task that triggers propaganda campaigns and consumes ever greater lots of tax money, only indicates that migration today incarnates the tensions of the political as such.

For evidence, it is enough to consider the simple fact that migration for a long time already has been a site of massive political mobilization. The term may rally people around building a Great Wall, transforming borders into sites of selection and cruelty - what Richmond (1995) once called global apartheid and what Bolt (2017) twenty years later defines as neo-fascism. However, the mobilizing potential of migration is observable not only at the extreme right of the political spectrum, where migrants were always identified as enemies. In liberal discourse, a transformation has occurred to the effect that the migrant is nowadays often invested with spurious qualities and antagonistic attitudes that threaten gender equality, sexual rights, security, and civilization (Murray 2017; Luce 2017; Goodhart 2017; for a critical account see Mishra 2017), and this stands in contrast to humanitarian rhetoric that has transformed the migrant from a guest or stranger into a suffering subaltern, but also to left-cosmopolitan discourse for which migration often forecasts a vitalization of democratic politics, an emerging culture of solidarity, a new idea of transnational citizenship (Isin 2012), or a belated ‘decolonization of Europe’ (Bhambra and Narayan 2016).

A first conclusion is thus clear. That migration and migrant presence emerge as Europe's major issue means that migration forces us to address the political as such. This conclusion generates additional questions. From the perspective of the bounded polity, efforts to address the political typically imply changes in existing systems of inclusion and exclusion. It is thus no surprise that the tensions that I have outlined often snap in struggles over citizenship. Who 
are we? Who are the others? Who can become a citizen? Who cannot? Where should we draw the boundary between us? Should there be a boundary? That growing numbers of Europeans take such questions to be of primordial urgency shows something: in the guise of migration, the constitutive antagonisms of the political are invading the polis.

Social theory cannot resolve such questions, but it can explain their historical conditions of emergence and clarify the ethical viability of different answers to them. Where was the political visible in past epochs of modern democracy? Then, too, it was visible in struggles around rights of residency, citizenship and political representation. Importantly, however, such conflicts were played out in two modalities, as it were (Wallerstein 1979; Balibar and Wallerstein, 1991; Bhambra 2014).

Within the territorial boundaries of European nations, conflicts stratified the polity in terms of class and gender and were thus mainly expressed in the struggle for democratic rights of the workers' movement and the women's movement. Those who opposed these movements denounced them as primitive, disordered, and agency-less 'masses' which endangered civilized culture and rational political order. To be sure, racial and ethnic distinctions were also mobilized in these conflicts, as protesting workers and women were regularly depicted as savages and barbarians within.

Outside the European realm of these state polities, i. e. in the territories and spheres of influence which where appended to them in the form of colonies, the social world was stratified mainly by the colonial difference (Mignolo 1999). Here, conflicts were more palpable and violent as they took the form of colonial subjugation, forced labour, slavery and resistance. Of course, differences pertaining to class and gender were often deployed to justify and sustain the colonial divide, yet racialization constituted the dominant antagonism.

Appearing in dual modalities, these struggles generated dual outcomes. Within the European territories of the imperial-nation states the struggle over the political led to 'the compromise' of universal suffrage and social welfare, with nationalism as an ideological solution that secured internal peace by boosting external antagonisms. In the imperial-colonial sphere, by contrast, the struggle led to a geopolitical settlement whereby imperial states were forced to cede sovereignty while at the same time retaining economic and military dominance, with the 'compromises' of decolonization and 'development' offering a measure of legitimacy to the new arrangement. Even so, the 'color line' remained an organizing barrier, separating core from periphery but also, in accord with the needs of capitalist accumulation, preserving inequalities within the populations of core or periphery (Guénif-Souilamas 2016). 
The emergence of migration as Europe's major political issue seems to indicate a process whereby the two sides of this system are collapsing into one another, in both real and metaphorical terms. Are we, then, as some argue (Sassen 2007; Appadurai 2006), witnessing the slow undoing of the precarious settlement that characterized the political and economic world order of late modernity - an undoing that is particularly chaotic and portentous along the real and metaphoric 'borders of Europe' (Balibar 2005) that once stabilized this dualistic system of inequality?

This indicates that the reasons why migration has political leverage in the present cannot be elucidated unless the history of colonialism and racism is moved to the centre of European history. As Fatima El-Tayeb (2008), among others, has shown, policies for a fair reception and integration of migrants in Europe are bound to fail - or are meaningless - if it is not recognized that these migrants also evoke the buried and repressed history of empire. Ongoing research and debate on the colonial legacies of Europe would thus, El-Tayeb argues (2008: 653), offer 'a perfect opportunity to overcome the structural (self-) exclusion of migrants and minorities so often lamented in mainstream discourses'. However, as the search for Europe's common history is still oriented inwardly, this opportunity is lost (Jonsson and Willén 2016); and 'the myriad ways in which minorities and migrants are part of this history' are not recognized in the public sphere (El-Tayeb 2008: 653). In sum, migration as an instance of the political concerns not just immigrant participation within the contemporary political arena, but it demonstrates how the very demarcation of that arena has been and continues to be conditioned by selective national ideas of cultural memory and ethnic affiliation, by racialization and deeply rooted colonial legacies, and by the continued dominance of historiographic 'continentalism' (Lewis and Wigen 1997: 30-37). Once this is revealed, colonialism and imperialism can no longer be seen as external to European sociology and history.

'Border struggles', a term coined by many and picked up by several contemporary thinkers (for overview, see Mezzadra and Neilson 2013: 1-26), is an apt description of the predicament that moves into focus once political theory recognizes migration as a major concern. The term indicates that the political struggles that are likely to define the future are no longer primarily those that involve parliaments and parties but those that concern borders of exclusion and inclusion, which in turn determine the extension of the political community and the criteria for qualifying as a citizen.

It is in this context that we should resituate Wendy Brown's (2010) widely spread argument that we now live in a 'post-Westphalian' global order, characterized by the 
disappearance of nation-state sovereignty. Having emerged in Europe after the Peace of Westphalia in 1648, having become a dominant political structure in Europe after the bourgeois revolutions of the nineteenth century, and having been rolled out globally after decolonization, the nation state is today challenged by political, social, cultural and economic forces that are not regulated by either nation or state. Brown claims that the decline of the sovereign state and the fading of territorialized sovereignty explain the peculiar fact that simultaneously with celebrations of the limitless world of globalization we also witness a rapid increase in efforts to control flows of humans and goods through physical walls, fences and barriers (Brown 2010: 22).

While Brown neglects the fact that virtually all the original 'Westphalian nation states' were also imperial states whose colonial sovereignty was always contested ${ }^{1}$, her argument about the ways in which borders reconfigure desires and identities is compelling. She contrasts two figures of human subjectivity (Brown 2010: 39-41). The first one is rootless, right-less and criminalized - homines sacri, as Giorgio Agamben (1998) calls them; the other one is obsessively concerned with homeland security. Drawing on Greg Eghigian's analysis of communist East Europe, Brown calls this second type homo munitus: conformist, passive, paranoid and predictable (Brown 2010: 41; cf. Eghigian 2008). In these two figures, a human being without rights and protection faces a human being protected by high-tech shields and weaponry. In this sense, theoretical discourse replicates the binary of the migrant and the fascist that, as noted above, haunts the public imaginary of Europe.

Brown's view seems emblematic of the ways in which the increasing interest in society's constitutive political processes leads us to question how collective identities are established, consolidated and upheld by way of boundaries - territorial, biometric, physical, economic, anthropological and, above all, eminently political. In this sense, she repeats a question that Etienne Balibar introduced in a seminal essay at the end of the 1990s: 'What is a Border?' In the wake of the East European Mauerfall, Balibar codified the apparent paradox that is at the heart of later theories such as Brown's. Globalization entails new forms of enclosure just as much as, or even more than it opens new channels. As he stated, borders no longer just demarcate a territory but they occupy it and cover the entire ground: 'borders are no longer the shores of the political, but have indeed become - perhaps by way of the police, given that every border patrol is today an organ of "internal security" - objects or - let us put it more precisely - things within the space of the political itself' (Balibar, 2002: 92).

\footnotetext{
${ }^{1}$ I am indebted to Peo Hansen for this observation.
} 
One advantage with Balibar's work is its precise analysis of the border as the preeminent scene of violence (2002: 138). This is where politicians get their hands dirty. Furthermore, borders give rise to contempt and brutality, be it in the form of the behaviour of occupying soldiers against civilians or in the methods used by European security services in the deportation of asylum seekers (Jones 2017). The border constitutes a specific modality of power that invests its guardians with a right to ignore ethical safeguards.

In this context, Balibar (2002: 85) quotes the French psychoanalyst André Green: 'You can be a citizen or you can be stateless, but it's difficult to imagine how you can be a border.' What would it mean to be a border, Balibar asks? A life lived nailed to the fence, or in the noman's land between the border controls of different states? You're not let in. You can't turn back. You get caught by the frame.

Such reflections warrant the proposition that there are today a number of people about whom we can say that they are borders in the sense just described. We may get a sense of the implication of this proposition by considering a life where one's 'migration status' is an object of constant, daily surveillance and control - in schools, public institutions and libraries, at hospitals and clinics, by landlords, employers and even neighbours. A life so affected by never-ending 'border checks' generates structures of subjectivity which are constantly interrogated and forced to justify their presence in and access to the public arena. Such subjectivities are comparable to borders in the sense described by Balibar.

This leads to an exceedingly difficult question: how to relate the category of people who are borders to the category of people who we designate as migrants? From a legal or empirical point of view, it is hardly reasonable to place all migrants in this category. Yet, the suggestion that migrants are borders generates possibilities for conceptualizing the polity in ways that question inherited conceptions of how belonging and mobility affect somebody's identity. The migrant will no longer be defined solely as a negation of a normative and often idealized model of sedentariness and belonging; nor will s/he be described as 'uprooted', as a newcomer in the process of integration, whose dual or multiple identities we can understand as simple traces of 'lost homelands'. In sum, the migrant will no longer be defined primarily by categories of 'identity'. Rather, s/he will be defined as 'a being in situation', as Sartre (1948/1995) once had it, the situation in question being characterized by the proximity to the border and a corresponding structure of affect, belief and action.

Such subjects embody what I have been calling 'the political'. On their very bodies we glimpse the ways in which political communities are today reconstituted and transformed. 
This is the deep context underlying many contemporary concepts in migration studies, such as deportability, permanent temporariness and precarity (Schierup et al. 2015).

As I demonstrated above, sustained reflection on contemporary migration as a political issue enables us also to break the impasse in scholarship that posits colonialism and imperialism as external to European sociology and history. We now see that reflection on migration and borders also generates an idea of migrant subjectivity as a political factor that offers us a method for breaking the third impasse, which concerns the inability of the social sciences to fully account for collective protests and social movements of emancipation as constitutive elements of democracy. It is precisely this issue that is at stake in the recent turn to agency in theories of migration.

\section{A turn toward 'agency' in migration studies}

My starting point is Thomas Nail's The Figure of the Migrant. This book releases a torrent of interesting notions and models that help us rethink political philosophy from the point of view of mobility and the migrant. As Nail puts it, migration has hitherto 'been predominantly understood from the perspective of stasis and perceived as a secondary or derivative figure with respect to place-bound social membership' (Nail 2015: 3). It follows from this, he claims, that migration has 'been predominantly understood from the perspective of states' (Nail 2015: 4). The weight with which migration imposes itself on politics and scholarship today forces us to reconsider this paradigm, Nail argues. The contemporary situation makes evident what previous historiography and social science have failed to recognize: 'that the figure of the migrant has always been the true motive force of history' (Nail 2015: 7).

Nail's project is to reconfigure 'flows', as he puts it, as a phenomenon that is primary to territorialized power structures. Hence a theoretical framework built on the opposition of 'kinopower' and 'pedic motion'. Kinopower is a force that contains mobility, synchronizing the movement of human subjectivities as well as the cycles of biological and geological processes to the circulation and accumulation of value. It stands for the means by which movement is controlled and exploited through various forms of containment and expulsion. By contrast, pedic motion ('ped' means 'foot') is a counterforce exercised by human individuals and communities for the purpose of securing a life where they are free to move and live as they want. To note, Nail's 'migrant' is no empirical entity; the concept refers to a generic agency - appearing in several historical incarnations - that employs pedic force to circumvent the machinations of kinopower. 
Borders and boundaries are not primary concepts in Nail's theory. Rather, boundaries are what he calls 'junctions'. That is, they are situations where 'flows' are blocked, diverted, dammed up or filtered; they are sites of encounter between the controlled circulation of kinopower and the pressures exerted by the pedic motion of the migrant (Nail 2015: 27-29). In this sense, junctions are political situations, where 'regulated circulation' encounters 'social oscillation' as practiced by those who are not fully part of the logic of circulation or are expulsed by it. Hence, junctions are also sites of selection and sorting.

In one sense, Nail concurs with state-centred political theorists on the topic of borders. $\mathrm{He}$, too, regards borders as materializations of socio-political systems that assert who belongs and who do not belong to the polis. Such systems are often made visible by the policing measures of inclusion and exclusion, involving a biometric monitoring of the migrant's body as well as an assessment of his/her potential values and opinions. What distinguishes Nail's paradigm, however, is that it establishes a counter-perspective, allowing us to theorize countervailing forces of resistance against such processes of sorting and selection. By this route, he arrives at the contested topic of migrant agency and resistance.

Another crucial reference in this context is Michael Hardt and Antonio Negri's remarks in their three-volume work Empire, Multitude and Commonwealth. The 'multitude', in their view, shows itself in 'Exodus': in the movement of bodies, in flows of refugees and migrants, in workers' strikes and flights from social structures that prohibit people from living and producing as free subjects (Hardt and Negri 2009: 150-164). When economic and political conditions turn oppressive, people have a tendency to revolt, Hardt and Negri argue. Generally, however, people try other options first, one of them being migration to more tolerable conditions. How many revolutions were Europe 'spared', we may ask, because millions from the continent's lower classes were served a chance to colonize the Americas?

Nail's historical ontology of kinopower may serve as a foundation for Hardt and Negri's affirmation of the multitude's migratory movement. For an empirical illustration, I turn to Amir Heidari, a political activist who for long periods was imprisoned in Sweden. Heidari was convicted for 'migrant smuggling'. Proudly claiming that he has helped 37,000 asylum seekers to Sweden, and as many as 200,000 if we add destinations such as Germany, Great Britain and Canada, he consistently rejects the accusation that he has engaged in illegal activities for financial gain. In his view, he is part of a resistance movement. Anticipating Vittorio Longhi's (2012) pamphlet about a coming 'immigrant war', Heidari has spoken of 'refugees [as] a new military power without weapons': 'They neither rely on nor believe in the world order that has been created. Neither do they recognize where the borders have been 
drawn.' As for himself: 'I have made myself a spokesperson for those millions around the world who do not have any representation, are persecuted or exploited. That they move to countries which have enriched themselves on their labour is no less than a revolution without arms.' (Ramqvist and Wirtén 2005).

As Heidari argued in 2005, the search for safety, security, work, or any kind of betterment will inevitably, when aggregated to a collective level, become a social movement, a pedic pressure. This pressure has been conceptualized in terms of 'the autonomy of migration' or 'autonomous migration' (Moulier-Boutang and Garson 1984; Papadopoulos and Tsianos 2007; Bojadzijev and Karakayali 2010; Tsianos and Karakayali 2010; Tazzioli 2015; de Genova 2017). In part, these conceptualizations are indebted to Gilles Deleuze and Félix Guattari's ontology of mobility, codified in A Thousand Plateaus (1987). Migration is here patterned on an idea of deterritorialization that connects the figure of the migrant to productive and emancipatory processes of 'becoming'. At the heart of this endeavour is a conceptual elaboration that enables us to conceive of migration as a trans-border social movement in its own right, with specific voice and agency, irreducible to the apparatus of the state. This perspective appears more dynamic than Wendy Brown's static antagonism between homo sacer and homo munitus, or Agamben's preordained schema where the ghastly nomos of the camp encounters naked, disposable life.

This is not to say that studies of migration can do without concepts of sovereignty and state power. However, in an era where migratory flows are increasingly conditioned by economic and climate-related circumstances, state power affects migration processes mainly as a reactive force, in the form of borders and camps that block, control or exploit movement (Castles and Miller 2009: 205). The central question thus remains: how to assess the political agency of migrants vis-à-vis efforts by state and capital to control and exploit it? On the face of it, the 'pedic force' exercised by asylum seekers, labour migrants and activist organizations that support them seems weak when compared to the 'kinopower' of states. We may admit, with de Genova (2017: 13), that the 'crisis of border control and migration management' in contemporary Europe speaks of 'a crisis of sovereignty that is repeatedly instigated, first and foremost, by diverse manifestations of the autonomous subjectivity of human mobility itself'. But then we should immediately add the qualification that instigation of a crisis of sovereignty does not translate into a challenge to or undoing of that sovereignty.

In so far as migration has thrown the EU and its member states into a crisis, this is not because it in threatens the sovereignty of these countries, but rather because it prompts the EU and its member states to painfully renegotiate their relation not just to their own citizenry but 
also to international law and human rights. Resulting from this is an apparent contradiction, between a Europe that protects its borders and a Europe that upholds human rights - or the ostensible dilemma that European states believe they must either act in the name of national sovereignty or the 'national people' (against migrants) and thus betray human rights, or act in the name of human rights (on behalf of migrants) and thus betray national sovereignty and the 'national people'.

Yet, what the political history of forced migration teaches us is that the right to asylum, as well as the obligation of societies to accommodate people in need of protection, have rarely encroached on state sovereignty; on the contrary, sanctuary practices have often depended on the existence of sovereign power (Rabben 2016; Lippert and Rehaag 2013). If today asylum rights and state sovereignty appear to contradict one another, this is therefore not to be seen as a historical verity but as one of the forms in which anti-immigration ideology and Eurocentric white supremacy are made manifest in the present political conjuncture.

The point to be grasped, then, is that in so far as migration can be seen as a social movement with a potential to transform Europe politically, as argued by Ilker Ataç, Kim Rygiel and Maurice Stierl (2016), it must be reckoned that the legitimizing force of this movement (its ideational superstructure, as it were), consists of policies and organizations that in the face of such nationalist and racist mobilization defend the universal applications of human rights and seek to ensure that sovereign states adhere to those universal principles in their jurisdiction and management of migration. Several organizations that work for migrant and refugee rights operate on the premises of article 14 on the rights of asylum in the UN's Universal Declaration of Human Rights, the Geneva Convention on the status of refugees and the UN's Refugee Convention (both 1951), or the ILO's conventions (1949 and 1975) that defend migrant workers against labour market exploitation. Some kind of appeal international law and its codification of the right of migrants vis-à-vis states, or the obligations of states to migrants, therefore seems essential for the recognition of migrant agency.

This emerging alliance between migrant groups claiming human rights and NGO's protecting those rights seems to substantiate Samuel Moyn's (2010) idea that human rights today constitute the only utopia left standing, a remnant of emancipatory ideals that animated the history of modernity over more than two centuries. Blueprints for a just global governance of migration, ensuring migrants' rights to asylum or fair labour standards, and insuring them against exploitation and exclusion, foreshadow a world order that consolidates migrant agency as a political force (Likic-Brboric 2018). Yet, notwithstanding their emancipatory potential, such blueprints for human rights constitute a weak idea of progress if compared to 
past forms of political emancipation such as the workers' movement, the women's movement and third-world anticolonial movements, all of which accomplished deep and lasting social transformations. Barring important exceptions (which coincide with human rights struggles against Communist regimes as in East Europe around 1989), contemporary human rights discourse seldom advocates systemic social transformation, although few would deny that this is what a credible realization of migrant rights as human rights would require. At best, the human rights regime allows the migrant subaltern to find legal protection and material sustenance in a new country. Yet, the conditions for such arrangements are becoming more austere by the day, and what human rights realistically can accomplish is rarely no more, but also no less, than the mere survival of people. Such is the contradictory manner in which the EU and its member states protect themselves from migrants while at the same time upholding international human rights, or its pretence. Migrants are rescued, but only to be deported.

If this is the political contradiction that emerges from a closer look at contemporary migration, it must be acknowledged that it also raises a theoretical dilemma. I have referred to the idea that migration constitutes an autonomous force, which is primary and prior to the formation of the state and which should be politically recognized on this basis: 'in the beginning there was mobility'. But I have also submitted that the migrant can assert this 'primary' right only by appealing to a framework of human rights and global governance that is agreed to and upheld by states. This is a version of the double bind that Hannah Arendt observed in her discussion of the refugee's 'rights to have rights'. As she argued, human rights are conveniently secured for those who are citizens of a state. But migrants without protection from any state, and who are therefore in the greatest need of human rights, have few if any ways of claiming such rights unless a state or other kind of sovereignty is willing to acknowledge them: 'The Rights of Man, supposedly inalienable, proved to be unenforceable even in countries whose constitutions were based upon them - whenever people appeared who were no longer citizens of any sovereign state.' (Arendt 1948/1979: 293)

On what grounds, then, shall the rights of migrants be defended? This fundamental issue divides political theory and migration studies as well as political debate in general. Migrant rights may be defended by appeals to what Arendt called natural rights: regardless of states, every person is endowed with a capacity for mobility that should be exercised freely. This alternative is today often coded in Deleuzian language that posits the migrant as a figure of potentiality and social transformation, yet often without considering that international law already invests the migrant with a legal status that states are obliged to recognize. In this light, the problem is not that the migrant is deprived of rights, or of the rights to have rights, but that 
these rights are systematically violated or rendered vacuous (Noll 2007). Again, migrants are rescued, but only to be deported. Rights to asylum and due process remain mere principles because the emergence of a system of border controls that constantly sifts and sorts people and population 'flows'. In this situation, what is needed is not only a general harmonization of state migration laws with international law, but enforcement of international law, in the absence of which it will be enforced clandestinely by the inventive, border-crossing agency of migrants themselves assisted by anonymous networks of solidarity.

However, migrant rights may also be upheld with reference to civil rights, a path interestingly analysed by Engin Isin (2012). Each human being has a right to citizenship, which also entails the right to mobility. Etienne Balibar captures this alternative concisely:

'Surely freedom of movement is a basic claim that must be incorporated within the citizenship of all people (and not only for representatives of the 'powerful nations', for whom this is largely a given). But the droit de cité (rights to full citizenship) includes everything from residential rights as part of having a 'normal' place in society to the exercise of political rights in those locations and groupings into which individuals and groups have been 'thrown' by history and the economy. Let's not be afraid of saying it: these citizenship rights include the manner of their belonging in state communities, even, and indeed especially, if they belong to more than one such community. Given the above, the right to full citizenship is indissolubly linked to freedom of movement.' (Balibar 2003: 42)

My point here is similar to the one I made above in regard to borders and identities. Concerning first principles upon which claims for migrant agency can be made - be it in the form of universal human rights, states' obligations to grant hospitality, an extended civil right to mobility, international law, or Arendt's ethico-political plea for the right to have rights social theory is a poor guide. To break this impasse, a perspective is needed that accounts for migration as 'normal', to paraphrase Balibar, rather than exceptional in the political constitution of political community and citizenship.

A society, which is not: concluding remarks

A perspective that accounts for migration as 'normal'? A view that places citizen and migrant on an equal level, not as opposite poles in a binary constellation or as the top and bottom of a hierarchy? What could it mean, sociologically and theoretically, to ask for such a perspective? 
This is the place to reconnect to Adorno's argument with which I began this essay: 'only the person who can conceptualize a different society from the existing one can experience it as a problem. Only through that which it is not, will it reveal itself as that which it is [...].'

(Adorno 1969/1976: 120). As long as migration research confines itself only to problems that can be resolved within the current system, it is likely to adopt a state-centred perspective that turns the sociology of migration into a matter of 'public administration', as Adorno put it, and often with the purpose of refining migration policy by finding the right balance between the ostensibly conflicting interests of citizens vis-à-vis foreigners. By contrast, and this was Adorno's alternative, it is only by acknowledging that ours is not a society in which migration is seen as normal and migrants enjoy human rights, that we attain real knowledge about the violent nature of the current migration regime.

A 'normalization' of the position of migration within the human sciences requires that we reframe established models of the polity, which are often bound to the nation-state model, and develop less territorialized notions of sovereignty, citizenship and belonging. More specifically, there seems to be a need to historicize migration and bordering processes. Migration would then no longer be considered, as in much political science, as a spatial 'jump' from one form of governance to another, but as a temporal process across porous boundaries. Correspondingly, bordering also be reframed as a temporal process, in which 'inclusion' and 'exclusion' are rarely disjunctive positions but matters of degree and positionality on a transversal scale that is ultimately governed by prevailing relationships of power between several collective agents, and not just by the inevitably asymmetric relation, which we experience at the passport control, of a dominant state sovereignty and a subaltern migrant agency. Such a reframing is under way in some of the most interesting departures in interdisciplinary migration studies, appearing under rubrics such as transnational migration systems (Basch, Glick-Schiller and Szanton Blanc 2005), border practises (Mezzadra and Neilson 2013; Tshabalala 2017), transformations of class, race and gender in globalized systems of labour migration (Schierup et al. 2015) and the ensuing mobilization of migration movements (Soysal 1994; Isin 2012; de Genova, ed. 2017).

To be sure, social movements that appear outside established political orders typically own weak political leverage, and the movement of migrants is a case in point. If their sociopolitical purchase is recognized at all, it is often perceived as a social problem and subjected to state interventions through policy or police. Sociological discourse (Sawyer $2002 ; 2005)$ has described such movements as cases of 'social emergence'. This is sometimes 
followed by what we may call 'political emergence', which involves collective mobilization and public voice.

To say that migration entails new forms of political emergence amounts to the proposition that migration today constitute a 'hypothesis' of a coming society. Over the past two-three decades, the human sciences have begun to explore this hypothesis. Numerous 'case studies' in migration studies as well as postcolonial studies have indicated that the figure of the migrant should be counted among the main protagonists of our times and as an embodiment of economic and social changes. But if this is true, and if the political emergence of migration would be fully recognized, it is crucial to seriously address our current lack of adequate theoretical frameworks and the need to reconceptualize notions such as citizenship, borders, sovereignty, statehood and community. This is perhaps what it would mean to rethink the society which exists through a society which is not: to resituate scholarship within a context that recognizes migration, including the colonial legacies from where it derives and the agency that it exercises, as a political process constitutive of our future.

\section{References}

Agamben G (1998) Homo Sacer: Sovereign Power and Bare Life, trans. D Heller-Roazen. Stanford: Stanford UP.

Adorno, T W (1969/1976) 'On the Logic of the Social Sciences'. In: The Positivist Dispute in German Sociology, trans. Adey G and Frisby D. London: Heinemann, 105-122.

Appadurai A (2006) Fear of Small Numbers: Essay on the Geography of Anger. Durham Duke UP.

Arendt H (1948/1979) The Origins of Totalitarianism. New York: Harcourt, Brace, Jovanovich.

Ataç I, Rygiel K and Stierl M (2016) 'Introduction: The Contentious Politics of Refugee and Migrant Protest and Solidarity Movements: Remaking Citizenship from the Margins', Citizenship Studies, vol. 20 (5): 527-544.

Badiou A (1985) Peut-on penser la politique. Paris: Seuil.

Balibar E (2002) Politics and the Other Scene, trans. C Jones et al. London: Verso.

Balibar E (2003) 'Europe, An 'Unimagined' Frontier of Democracy'. Diacritics 33 (3-4): 3644. 
Balibar E (2005) Europe Constitution Frontière. Bègles: Ed. du Passant.

Balibar E and I Wallerstein (1991) Race, Nation, Class: Ambiguous Identities. London: Verso.

Basch L, Glick-Schiller N and Szanton Blanc C (2005) Nations Unbound: Transnational Projects, Postcolonial Predicaments, and Deterritorialized Nation-States. London and New York: Routledge.

Bhambra GK (2014) Connected Sociologies. London: Bloomsbury Academic.

Bhambra GK and Narayan J (2016) European Cosmopolitanism: Colonial Histories and Postcolonial Societies. London: Routledge.

Boatca M (2015) Global Inequalities Beyond Occidentalism. London: Routledge.

Bojadzijev M and Karakayali S (2010) 'Recuperating the Sideshows of Capitalism: The Autonomy of Migration Today'. e-flux journal, no. 17 (June-August). Available at: http://www.e-flux.com/journal/17/ (accessed 4 March 2017).

Bolt M (2017) Trumps kontrarevolution. Copenhagen: Nemo.

Brown W (2010) Walled States, Waning Sovereignty. Cambridge: The MIT Press.

Castles S and Miller M J (2009) The Age of Migration: International Population Movements in the Modern World, fourth ed. Houndmills, Basingstoke: Palgrave Macmillan.

de Genova N (ed) (2017) The Borders of 'Europe': Autonomy of Migration, Tactics of Bordering. Durham: Duke UP.

Deleuze G and Guattari F (1987) A Thousand Plateaus: Capitalism and Schizophrenia. Minneapolis: Univ. of Minnesota Press.

Eghigian G (2008) 'Homo munitus: The East German observed'. In: Socialist Modern: East German Everyday Culture and Politics, ed. by K. Pence and P. Betts. Ann Arbor: Univ. of Minnesota Press, 37-70.

El-Tayeb F (2008) 'The Birth of a European Public: Migration, Postnationality and Race in the Uniting of Europe,' American Quarterly, vol. 60: 3, pp. 649-670.

Financial Times (2015) 'Person of the Year: Angela Merkel - The transformation of a cautious chancellor', 13 December. Available at: https://www.ft.com/content/ffb1edb2$\underline{9 \mathrm{db} 5-11 \mathrm{e} 5-\mathrm{b} 45 \mathrm{~d}-4812 \mathrm{f} 209 \mathrm{f} 861}$ 
Goodhart, D (2017) The Road to Somewhere: The New Tribes Shaping British Politics (London: Penguin, 2017).

Guénif-Souilamas N (2016) "Restrained Equality: A Sexualized and Gendered Colour Line". In: Jonsson and Willén (eds) Austere Histories in European Societies: Social Exclusion and the Contest of Colonial Memories. London: Routledge.

Hansen P and Hager S (2012) The Politics of European Citizenship: Deepening Contradictions in Social Rights and Migration Policy. New York: Berghahn Books.

Hansen P and Jonsson S (2014) Eurafrica: The Untold History of European Integration and Colonialism. London: Bloomsbury Academic.

Hardt M and Negri A (2009), Commonwealth. Cambridge: Harvard UP.

Isin E (2012) Citizens Without Frontiers. London: Bloomsbury.

Jones, R (2017) Violent Borders: Refugees and the Right to Move. London: Verso.

Jonsson S (2013) Crowds and Democracy: The Idea and Image of the Masses from Revolution to Fascism. New York: Columbia UP.

Jonsson S (2016) 'Monstruösa historier: Utkast till protestens poetik'. In Lorenzoni P and Manns U (eds) Historiens hemvist, vol. 2: Etik, politik och historikerns ansvar. Gothenburg: Makadam förlag, 2016.

Jonsson S and Willén J (eds) (2016) Austere Histories in European Societies: Social Exclusion and the Contest of Colonial Memories. London: Routledge.

Juncker, J-C (2016) 'State of the Unioin 2016'. Available at: https://ec.europa.eu/priorities/state-union-2016_en

Lefort C (1983) La question de la démocratie'. In Le Retrait du politique: Travaux du Centre de Recherches Philosophiques sur le Politique. Paris: Galilée.

Lewis M and Wigen K (1997) The Myth of Continents: A Critique of Metageography. Berkeley and Los Angeles: University of California Press.

Likic-Brboric, B (2018) 'Global migration governance, civil society and the paradoxes of sustainability'. Globalizations 15 (6), 762-778.

Lilla M (2017) The Once and Future Liberal: After Identity Politics. New York: Harper. 
Lippert R K and Rehaag S (2013) Sanctuary Practices in International Perspectives: Migration, Citizenship, and Social Movements. London and New York: Routledge.

Longhi V (2012) The Immigrant war: A global movement against discrimination and exploitation. Bristol: Policy Press.

Luce E (2017) The Retreat of Western Liberalism. New York: Little, Brown.

Mezzadra S and Neilson B (2013) Border as Method; or, the Multiplication of Labor. Durham: Duke UP.

Mignolo W (1999) 'Philosophy and the Colonial Difference'. Philosophy Today 43 (1). Mishra P (2017) 'What Is Great about Ourselves', London Review of Books 39 (18): 3-7. Mouffe C (2005) On the Political. London Routledge.

Moulier-Boutang Y and Garson J-P (1984) 'Major Obstacles to Control of Irregular Migrations: Prerequisites to Policy. International Migration Review 18 (3): 579-92.

Moyn S (2010) The Last Utopia: Human Rights in History. New York: Columbia UP.

Murray D (2017) The Strange Death of Europe: Immigration, Identity, Islam. London: Bloomsbury.

Nail T (2015) The Figure of the Migrant. Stanford: Stanford UP.

Noll, G. (2007). 'Why Human Rights Fail to Protect Undocumented Migrants'. European Journal of Migration and Law, 12(2), 241-272.

Papadopoulos D and Tsianos V (2007) 'The Autonomy of Migration: The Animals of Undocumented Mobility’. In Hickey-Moody and Malins (eds) Deleuzian Encounters: Studies in Contemporary Social Issues. London: Palgrave Macmillan, pp. 223-235.

Rabben, L (2016) Sanctuary and Asylum: A Social and Political History. Seattle: University of Washington Press.

Ramqvist K and Wirtén P (2005) ‘Är han Sveriges fiende?’, Arena, no. 6, pp. 1217.

Richmond A (1995) Global Apartheid: Refugees, Racism, and the New World Order. Oxford: Oxford UP.

Sartre J-P (1948/1995) Anti-Semite and Jew, trans. Becker GJ. New York: Vintage.

Sassen S (2007) Territory, Authority, Rights. Princeton: Princeton UP. 
Sawyer R (2002) 'Durkheim's Dilemma: Toward a Sociology of Emergence', Sociological Theory, 20 (2): 227-47.

Sawyer R (2005) Social Emergence: Societies as Complex Systems. Cambridge: Cambridge UP.

Schierup C-U et al. (2015) Migration, Precarity, and Global Governance: Challenges and Opportunities for Labour. Oxford: Oxford UP.

Schmitt C (1927/2007) The Concept of the Political, trans. G. Schwab. Chicago: Univ. of Chicago Press.

Soysal, Y N (1994) Limits of Citizenship: Migrants and Postnational Membership in Europe. Chicago: The University of Chicago Press.

Tazzioli M. (2015) Spaces of Governmentality: Autonomous Migration and the Arab Uprisings. London: Rowman and Littlefield.

Triandafyllidou A (2017) 'A “Refugee Crisis” Unfolding: "Real” Events and Their Interpretation in Media and Political Debates'. Journal of Immigrant and Refugee Studies.

Tshabalala, X (2017) Hyenas of the Limpopo: The Social Politics of Undocumented Movement Across South Africa's Border with Zimbabwe. Linköping: Linköping Studies in Arts and Science [Diss.].

Tsianos V and Karakayali S (2010). Transnational Migration and the Emergence of the European Border Regime: An Ethnographic Analysis. European Journal of Social Theory 13 (3): 373-387.

Wallerstein I (1979) The Capitalist World-Economy. Cambridge: Cambridge UP.

Wintour, Patrick (2018) 'Hillary Clinton: Europe must curb immigration to stop rightwing populists' [interview], The Guardian 22 November. Available at: https://www.theguardian.com/world/2018/nov/22/hillary-clinton-europe-must-curbimmigration-stop-populists-trump-brexit 